\title{
Moderating Effect of MNCs' Equity Ownership in the Relationship between Degree of Inter-Firm Technology Transfer and Local Firms' Performance
}

\author{
Sazali Abdul Wahab \\ National Defence University of Malaysia, Kuala Lumpur 57000, Malaysia \\ E-mail: saw@upnm.edu.my \\ Raduan Che Rose \\ National Defence University of Malaysia, Kuala Lumpur 57000, Malaysia \\ E-mail: raduan@upnm.edu.my \\ Suzana Idayu Wati Osman \\ Felda Global Ventures Holdings, Kuala Lumpur 54000, Malaysia \\ E-mail: suzana.iwo@gmail.com
}

Received: October 20, 2010

doi:10.5539/ijbm.v6n11p76
Accepted: April 29, $2011 \quad$ Published: November 1, 2011

URL: http://dx.doi.org/10.5539/ijbm.v6n11p76

\begin{abstract}
The inter-firm technology transfers (TT) through international joint ventures (IJVs), among others, have significantly contributed to a higher degree of local innovation performance/capabilities, technological capabilities, competitive advantage, organizational learning effectiveness, productivity, technological development of local industry, and the economic growth of the host country. Since the focus of inter-firm TT in developing countries has shifted to degree of technology transfer, organizations in developing countries are attempting to assess not only the significant role of technology transfer in strengthening their corporate and human resource performance but also the influence of other critical variables such as MNCs' size, age of JVs, country of origin, MNCs' equity ownership (MNCEQTY) and MNC's type of industries that could significantly moderate the relationship. Based on the underlying knowledge-based view (KBV) and organizational learning (OL) perspectives, the main objective of this paper is to empirically examine the moderating effect of equity ownership of MNCs (50/50 equal ownership between MNCs and local JV partners vs. minor/majority ownership by MNCs) in the relationships between degree of inter-firm technology transfer and two dimensions of local firms' performance: corporate (CPERF) and human resource (HEPERF) performances. Using the moderated multiple regression (MMR) analysis, the theoretical models and hypotheses in this study were tested based on empirical data gathered from 128 joint venture companies registered with the Registrar of Companies of Malaysia (ROC). The results revealed that equity ownership of MNCs has been established to provide a significant moderating effects in 1) TTDEG-CPERF relationship; where the relationship was found stronger for minor/majority ownership by MNCs as compared to 50/50 equal ownership between JV partners, and 2) TTDEG-HRPERF relationship; where the relationship was found stronger for 50/50 equal ownership between JV partners as compared to minor/majority ownership by MNCs. The study has bridged the literature gaps in such that it offers empirical evidence and new insights on the significant moderating effects of equity ownership of MNCs in the relationships between degree of inter-firm technology transfer and local firms' performance technology using the Malaysian sample.
\end{abstract}

Keywords: Degree of inter-firm technology transfer, Local firms' performance, International joint ventures, Equity ownership of MNCs, Malaysia

\section{Introduction}

When compared to various forms of strategic alliance such as distribution and supply agreements, research and development partnerships or technical and management contract, the international joint ventures (IJVs) are considered as the most efficient formal mechanism for technology transfer (TT) to occur via inter-partner learning between foreign MNCs and local firms (Kogut and Zander, 1993; Inkpen 1998a, 2000). IJVs are also viewed as the most efficient mode to transfer technology and knowledge which are organizationally embedded and difficult to transfer through licensing agreements (Kogut, 1988; Mowery, Oxley and Silverman, 1996). IJVs provide both MNCs and local partners an appropriate avenue to facilitate the transfer of organizational knowledge, particularly for knowledge which is hard to be transferred without the setting up of a JV such as institutional and cultural knowledge (Harrigan, 1984). 
A review of literature reveals that majority of empirical studies on inter-firm technology and knowledge transfer in strategic alliance particularly IJVs are limiting their focus on the performance of the IJVs (for example Lyles and Salk, 1996; Lane et al., 2001; Tsang et al., 2004; Dhanaraj et al., 2004; Steensma and Lyles, 2000). On the other hand, the performance of the MNCs' subsidiary and affiliate in the host countries has become the primary focus of intra-firm knowledge transfer literature (Chen, 1996; Chung, 2001; Cui et al., 2006; Lin, 2007). Most of the studies on strategic alliance and IJVs have recorded positive relationship between knowledge acquisition or transfer and IJVs' performance for example 1) knowledge acquisition has a positive impact on the IJVs' human resource, general and business performance (Lyles and Salk, 1996), 2) knowledge acquisition as a better predictor for human-resource related performance than the general and business performance (Lyles and Salk, 1996), 3) knowledge acquisition from parent firms has a significant positive effect on IJVs' performance (Lane et al., 2001; Tsang et al., 2004), 4) explicit knowledge acquisition have a positive impact on IJVs' performance (Dhanaraj et al., 2004), and 5) tacit knowledge about overseas information was positively related to new product development capacities (Subramaniam and Venkatraman, 2001). In addition, Yin and Bao (2006) found tacit knowledge acquisition had significantly affected local firms' performance (LFP). Interestingly, Dhanaraj et al. (2004) found tacit knowledge was negatively related to IJVs' performance.

Although many studies have acknowledged the significant effect of knowledge transfer on performance outcomes, nevertheless except for Yin and Bao (2006), studies which examine the effects of degree of technology transfer (TTDEG) on both local firms' corporate (CPERF) and human resource (HRPERF) performances in inter-firm TT are still scarce. Moreover, the relationships between TTDEG and both CPERF and HRPERF of local firms could possibly have been influenced by other established moderating factors such as size of MNCs, age of JV, MNCs' country of origin, MNCs' equity ownership, and MNCs' types of industry. In other words the variations in CPERF and HRPERF could have been significantly influenced or explained by these variables. Thus, this study fills in these literature gaps by specifically examining the effect of equity ownership of MNCs (50/50 equal ownership between MNCs and local JV partners vs. minor/majority ownership by MNCs) as a moderating variable in the relationships between degree of technology transfer (TTDEG) and two distinct dimensions of local firms' performance (LFP): corporate (CPERF) and human resource (HRPERF) performances. The primary objective is to provide new insights and information on the boundary conditions for TTDEG-LFP relationship (Aguinis, 2004).

\section{Theoretical Background and Hypotheses}

The current TT issue in developing countries revolves around the extent of degree of technologies that are transferred (TTDEG) by the technology suppliers to their recipient partners (Pak and Park, 2004; Minbaeva, 2007). The question is no longer whether or not the MNCs are transferring technology to local firms; instead the focus in the literature has shifted to questions on 1) the level (sophistication) of the transferred technology, and 2) the stage of the transfer process (Lai and Narayanan, 1997; Narayanan and Lai, 2000). Except for Pak and Park (2004) and Minbaeva (2007), not many studies in both intra and inter-firm TT have focused on TTDEG as independent or dependent variable. In general, bulk of the studies has focused more on technological knowledge and knowledge acquisition 'per se' as the outcomes. For example, the technology transfer, knowledge transfer (KT) and strategic alliance literatures have extensively examined the relationships between 1) knowledge attributes, source and recipient and KT success (Cummings et al., 2003), 2) knowledge seekers, knowledge holder and contextual factors and know-how acquisition (Hau and Evangelista, 2007), 3) IJVs characteristics and knowledge acquisition (Lyles and Salk, 1996), 4) knowledge actors' interaction and KT (Bresman et al., 1999), 5) organization motivation, learning capacity, learning hindrance and KT (Simonin, 2004), 6) absorptive capacity and knowledge learned from foreign firm (Lane et al., 2001), 7) the IJV characteristics and knowledge acquisition (Tsang et al., 2004), 8) knowledge antecedents, ambiguity and knowledge transfer (Simonin, 1999a), 9) learning intent, management control and managerial knowledge acquisition (Lin, 2005), 10) relational embeddedness and tacit/explicit knowledge acquisition (Dhanaraj et al., 2004), 11) overseeing effort, management involvement and knowledge acquisition (Tsang et al., 2004), 12) the supplier and recipient factors and tacit knowledge acquisition (Yin and Bao, 2006), and 13) relation-specific determinants, knowledge specific determinants and degree of knowledge transfer (Pak and Park, 2004).

Although the previous researchers have not specifically dealt with TTDEG as a variable, however, a number of studies have directly operationalized degree (amount) of technology transferred to the recipient firm in terms of the extent of type of technological knowledge that are transferred or acquired for instance 1) the tacit and explicit marketing knowledge (Hau and Evangalista, 2007), 2) the tacit and explicit knowledge (Dhanaraj et al., 2004; Yin and Bao, 2006), 3) the marketing know-how (Simonin, 1999b; Wong et al., 2002), 4) the technology in service industries (Grosse, 1996), 5) the knowledge on product development and foreign cultures (Lyles and Salk, 1996), 7) the technological learning (Lin, 2007), 8) the managerial knowledge (Si and Bruton, 1999; Tsang 2001; Luo and Peng, 1999; Liu and Vince, 1999; Lin, 2005), 9) managerial skills (Wong et al., 2002), 10) the technology or manufacturing know how (Lam, 1997; Bresman et al., 1999), 11) the business environment and product market knowledge (Geppert and Clark, 2003), and 12) the research and development (Minbaeva, 2007). In the context of inter-firm technological knowledge transfer in IJVs, only Pak and Park (2004) have directly dealt with degree of knowledge transfer as the outcome (dependent variable) with respect to the transfer of new product development and manufacturing skills/techniques.

The inter-firm TT and KT literatures have strongly acknowledged that a substantial transfer of technology, 
regardless whether tacit or explicit technology, will positively 1) lead to a higher potentials of innovation performance/capabilities (Guan et al., 2006; Kotabe et al., 2007), 2) increase technological capabilities (Kumar et al., 1999; Madanmohan et al., 2004), 3) enhance organizations' competitive advantage (Liao and Hu, 2007; Rodriguez and Rodriguez, 2005), 4) enhance organizational learning effectiveness (Inkpen, 2000; Inkpen and Dinur, 1998), 5) improve productivity (Caves, 1974; Liu and Wang, 2003), 6) increase technological development of local industry (Markusen and Venables, 1999), and 7) improve the economic growth of the host country (Blomstrom, 1990).

Both knowledge acquisition and knowledge transfer literatures have argued that equity ownership in IJVs, particularly shared management IJVs; where the partners' equity/share is split 50/50 between IJV partners, could significantly influence knowledge acquisition in IJVs when 1) appropriate controls can facilitate the organizational learning process by managing the dynamic internal processes of IJVs such as a balanced bargaining power and different need-configurations of partners (Makhija and Ganesh, 1997), 2) equity ownership enables the JV partners to interact and communicate easily thus creating opportunities to share and easy access to each partner's technologies, knowledge and competencies (Pak and Park, 2004), 3) shared management IJVs provides a strong strategic rationale of transferring and acquiring knowledge and skills of both partners (Salk, 1992), 4) acquiring tacit knowledge from a JV partner is less difficult through shared management as compared to simple contract-based relationship (Mowery et al., 1996), and 5) it determines the degree of resource commitment or equity interests as control is closely associated with the partners' ability to influence systems, methods, and decisions (Anderson and Gatignon, 1986). Nevertheless, few other researchers have also stressed that if no single partner has dominant controls in IJVs, the 50/50 ownership structure could 1) escalate difficulties when cultural differences are present (Killing, 1983), and 2) create parental tensions (Killing, 1983; Salk, 1992). Pak and Park (2004) further argued that even if the local JV partners were to have $49 \%$ equity in IJVs that does not guarantee them to have a higher influence in making decision related to major business operations; which include learning and acquiring new knowledge. On the other hand, quite often, a dominant equity ownership (more than 50\% equity ownership) by local JV partners will only discourage higher resource commitment by foreign MNCs therefore reducing the possibility for a higher technological knowledge transfer to local JV partners (Pak and Park, 2004). Studies have shown that equity ownership structure in IJVs has moderated 1) the relationships between cultural misunderstandings and written goal and knowledge acquisition from foreign parents (Lyles and Salk, 1996), and 2) articulated goal (Harrigan, 1986; Salk, 1992). Figure 1 below depicts the above relationships between degree of inter-firm technology, local firms' performance and equity ownership of MNCs.

H1: The equity ownership of MNCs moderates the relationship between degree of inter-firm technology transfer and local firms' corporate performance.

H2: The equity ownership of MNCs moderates the relationship between degree of inter-firm technology transfer and local firms' human resource performance.

\section{Methods}

Insert Figure 1 - here

\subsection{Sample}

The sample frame was taken from the IJV companies registered with the Registrar of Companies (ROC). As at $1^{\text {st }}$ January 2008, the number of IJVs operating in Malaysia was 1038. Out of this, 850 IJVs were considered as active IJVs and 103 IJVs were either dormant or had ceased operation. Since the focus of this study is on inter-firm TT from foreign MNCs to local companies, $85 \mathrm{IJVs}$ were further eliminated from the population frame because only IJVs that have operated more than 2 years and have at least twenty percent $(20 \%)$ of foreign equity are eligible to participate in the survey. Therefore, based on the list provided by ROC, which is considered as the most official and original source of information on foreign investment in Malaysia, it was decided that all IJVs (850) be included in the survey. Data collection was conducted in the period from July 2008 to December 2008 using a self-administered questionnaire. The questionnaires were mailed to 850 active JV companies as listed with ROC using a cover letter. After one month from the posting date the response was found not encouraging. By mid July 2008 there were only 70 responses received from the respondents. Thus, in order to increase the response rate the researcher followed-up through numerous phone calls, e-mails, reminders via letters and personal visits to seek the respondents' cooperation in the survey. After intensive efforts were made, by mid November 2008 a total of 145 responses $(17.05 \%)$ were received. Based on literature review, the response rates for mailed questionnaires are usually not encouraging and low (Sekaran, 2003). In the Malaysian context, however, a response rate of $15 \%$ to $25 \%$ is still being considered appropriate and acceptable (Mohammed, 1998). From 145 responses only 128 questionnaires were usable and 17 questionnaires were returned blank, incomplete, or replied but unable to participate in the study.

\subsection{Instrument and measurement}

The main research instrument in this study is the questionnaire. Building on the previous TT and KT studies, the questionnaire adopts a multi-item scales which have been modified accordingly to suit the context of the study: inter-firm TT. Except for degree of technology transfer (TTDEG), all the variables are measured using ten-point Likert Scale $(1=$ strongly disagree to $10=$ strongly agree $)$. For TTDEG, this variable is measured using ten-point Likert Scale $(1=$ very low transfer to $10=$ substantial transfer $)$. The ten-point Likert Scale was selected because 1) the wider distribution of scores around the mean provides more discriminating power, 2) it is easy to establish 
covariance between two variables with greater dispersion around their means, 3) it has been well established in academic and industry research, and 4) from a model development perspective, a ten-point scale is more preferred (Allen and Rao, 2000).

\subsection{Dependent Variable - Local Firms' Performance (LFP)}

This study operationalizes LFP from two dimensions of performances: 1) corporate performance (CPERF), and 2) human resource (competencies) performance (HRPERF). Based on literature review, the qualitative (objective) measures of companies' performance are the most practical and ideal measurement of performance. However, the concrete financial figures are neither available nor reliable (Lyles and Barden, 2000; Tsang et al., 2004). Past studies have shown a positive relationship between objective and perceptual (subjective) measures of firm's performance (Lyles and Salk, 1996; Dess and Robinson, 1984; Geringer and Hebert, 1989, 1991). Thus, this study applies subjective measures to measure LFP based on IJV's top management assessments using "a multi-dimensional performance indicators". The CPERF, as the first dimension of LFP, is measured by a four (4) items scale measuring business volume, market share, planned goals and profits. For HRPERF, as the second dimension of LFP, four (4) items are used to measure product/service quality, employees' productivity, managerial techniques/skills and operational efficiency (Tsang et al., 2004; Yin and Bao, 2006; Lane et al., 2001; Lyles and Salk, 1996). The Cronbach Alphas for CPERF and HRPERF were 0.926 and 0.97 respectively. The results of Cronbach Alpha were well above of Lyles and Salk (1996).

3.4 Independent Variable - Degree of Technology Transfer (TTDEG)

Following Lyles and Salk (1996), Lane et al., (2001), Gupta and Govindarajan (2000), Dhanaraj et al. (2004), Pak and Park (2004), Yin and Boa (2006) and Minbaeva (2007), this study adopts "a multi-dimensional operationalization approach" in measuring this construct. This study operationalizes TTDEG as the transfer of technological knowledge from two dimensions: 1) tacit knowledge (TCTDEG) in terms of new product/service development, managerial systems and practice, process designs and new marketing expertise, and 2) explicit knowledge (EXPDEG) in terms of manufacturing/service techniques/skills, promotion techniques/skills, distribution know-how, and purchasing know-how. The respondents were asked to evaluate TTDEG from MNCs to local firms in terms of tacit and explicit dimensions of technological knowledge. The Cronbach Alphas for TCTDEG and EXPDEG were 0.96 and 0.97 respectively. The results of Cronbach Alpha were quite similar to that of Hau and Evangelista (2007) and Yin and Bao (2006).

\subsection{Moderating Variable - Equity Ownership of MNCs (MNCEQTY)}

Following the previous studies (Lyles and Salk, 1996; Pak and Park, 2004), MNCEQTY is measured by the ownership structure of the JVs companies that were registered with ROC based on items coded: $0=50 / 50$ equal ownership between MNCs and local JV partners and 1 = minor/majority ownership by MNCs (Yin and Bao, 2006).

\subsection{Model and Analysis}

The moderated multiple regression (MMR) analysis is defined as an inferential procedure which consists of comparing two different least-squares regression equations (Aguinis, 2004; Aiken and West, 1991; Cohen and Cohen, 1983; Jaccard et al., 1990). Using the MMR analysis, the moderating effect of the variable (product term) was analyzed by interpreting 1) the $R^{2}$ change in the models obtained from the model summaries, and 2) the regressions coefficients for the product term obtained from the coefficients tables. Prior to conducting the MMR analysis, preliminary analyses were conducted to ensure that there was no violation of the assumptions of normality, linearity, homoscedasticity, and homogeneity of error variance. The population data was carefully examined to avoid the occurrence of 1) Type 1 error; which is the error of rejecting the true null hypotheses at a specified $\alpha$, and 2) Type 2 error ( $\beta$ ); which is the error of failing to reject a false null hypotheses at a specified power (Aguinis, 2004). In this study, Equation 1 below was used to represent the variables in the ordinary least-squares (OLS) model:

$$
\text { Equation } 1 \text { (OLS model): } \quad \mathrm{Y}=\beta 0+\beta 1 \mathrm{X}+\beta 2 \mathrm{Z}+e
$$

To determine the presence of moderating effect, the OLS model was then compared with the MMR model which was represented by Equation 2 below:

$$
\text { Equation } 2 \text { (MMR model): } \quad \mathrm{Y}=\beta 0+\beta 1 \mathrm{X}+\beta 2 \mathrm{Z}+\beta 3 \mathrm{X} * \mathrm{Z}+e
$$

where, $\mathrm{Y}=$ local firms' performance (CPERF and HRPERF as the dependent variables), $\mathrm{X}=$ degree of technology transfer, $Z=a$ hypothesized binary grouping moderator (MNCEQTY: 50/50 equal ownership between MNCs and local JV partners vs. minor/majority ownership by MNCs), $\mathrm{X} * \mathrm{Z}=$ the product between the predictors (TTDEG*MNCEQTY), $\beta 0=$ the intercept of the line-of-best-of-fit which represents the value of $Y$ when $X=0, \beta 1=$ the least-squares estimate of the population regression coefficient for $X, \beta 2=$ the least-squares estimate of the population regression coefficient for $Z, \beta 3=$ the sample-base least-squares estimates of the population regression coefficient for the product term, and $e=$ the error term. The moderating variable (product term) is a binary grouping moderator; where the moderating variable MNCEQTY was coded using the dummy coding system; $0=50 / 50$ equal ownership between $\mathrm{JV}$ partners and $1=$ minor/majority ownership by MNCs. This was done because of its simplicity and ease of interpretation of results when making comparisons between different groups (Aguinis, 2004). 


\section{Results}

Table 1 and Table 2 show the model summary for both corporate (CPERF) and human resource (HRPERF) performances. The coefficients for all variables for Model 1 and Model 2 (for both CPERF and HRPERF) are presented in Table 3 and Table 4. Table 1 shows that for Model $1, R=.674, R^{2}=.455$ and $[F(2,125)=52.137$, $p=.0001]$. This $R^{2}$ means that $45.5 \%$ of the variance in the CPERF is explained by TTDEG scores and MNCEQTY. Model 2 shows the results after the product term (TTDEG*MNCEQTY) was included in the equation. Table 1 also indicates that the inclusion of the product term resulted in an $R^{2}$ change of $.013,[F(1,124)$ $=3.072, p<0.10]$. The results support for the presence of a small significant moderating effect. To put it differently, the moderating effect of MNCEQTY explains only $1.3 \%$ variance in the CPERF above and beyond the variance by TTDEG scores and MNCEQTY. Thus, it can reasonably be concluded that hypothesis $H 1$ is supported.

Table 2 shows that for Model $1, R=.736, R^{2}=.542$ and $[F(2,125)=73.995, p=.0001]$. This $R^{2}$ means that $54.2 \%$ of the variance in the HRPERF is explained by TTDEG scores and MNCEQTY. Model 2 also shows the results after the product term (TTDEG*MNCEQTY) was included in the equation. Table 2 above indicates that the inclusion of the product term resulted in an $R^{2}$ change of $.035,[F(1,124)=10.385, p<0.01]$. The results show a presence of significant moderating effect. To put it differently, the moderating effect of MNCEQTY explains $3.5 \%$ variance in the HRPERF above and beyond the variance by TTDEG scores and MNCEQTY. Thus, it can safely be concluded that hypothesis $H 2$ is also supported. The coefficients table for CPERF as shown in Table 3 depicts the results of the regressions equation for Model 1 and Model 2.

Model 1 indicates that TTDEG was statistically significant $(p<0.001$; Beta value $=.665)$; however MNCEQTY was not statistically significant $(p>0.05)$. Equation 3 shows that for a 1-point increase in TTDEG, the CPERF is predicted to have a difference by .445, given that the MNCEQTY is held constant. The regression coefficient associated with MNCEQTY means that the difference in CPERF between 50/50 equal ownership between JV partners and minor/ majority ownership by MNCs is .145, given that TTDEG is held constant.

\section{Equation 3: $\quad$ CPERF $=.509+.445 \mathrm{TTDEG}+.145 \mathrm{MNCEQTY}$}

The high-order of interaction effects of the MMR test was conducted to differentiate the extent of CPERF that was influenced by 50/50 equal ownership between JV partners and minor/majority ownership by MNCs. Model 2 shows the results after the product term (TTDEG*MNCEQTY) was included in the equation. As indicated in Table 1 the inclusion of product term resulted in an $R^{2}$ change of $.013,[F(1,124)=3.072, p<0.10]$. Model 2 shows TTDEG and MNCEQTY were significant $(p<0.001$, Beta value $=.995 ; p<0.10$, Beta value $=.591$, respectively). Similarly, TTDEG*MNCEQTY was also found to be significant $(p<0.10)$. The results did support the presence of a small significant moderating effect. Table 3 also reveals information on the regression coefficients after the inclusion of product term in the equation. The equation for Model 2 is as follows:

Equation 4: $\quad$ CPERF $=-10.042+.666 \mathrm{TTDEG}+2.873 \mathrm{MNCEQTY}-.056 \mathrm{TTDEG} * \mathrm{MNCEQTY}$

As indicated above, the interpretation of the regression coefficients is based on the fact that the binary moderator was coded using the dummy code system. The result for Model 2 indicates that for a 1-point increase in the TTDEG, the CPERF is predicted to have a difference by .666, given that MNCEQTY is held constant. The interpretation of the regression coefficients for the product term in Equation 4 is that there is a -.056 difference between the slope of CPERF on TTDEG between 50/50 equal ownership between JV partners and minor/majority ownership by MNCs. In other words, the slope regressing CPERF on TTDEG is steeper for minor/majority ownership by MNCs as compared to 50/50 equal ownership between JV partners. The TTDEG and CPERF relationship for 50/50 equal ownership between MNCs and local JV partners and minor/majority ownership by MNCs is shown in Figure 1 below by creating a graph displaying the relationships for each of the groups (Aguinis, 2004). From the results of descriptive statistics, the value of the mean score for TTDEG is 6.19; and for the standard deviation $(S D)$ is 1.30 . Following Aguinis (2004), the value $1 S D$ above the mean is 7.49 and the value $1 S D$ below the mean is 4.89. Thus, using the value of $1 S D$ above and $1 S D$ below mean in Equation 4 yields the graph shown in Figure 1. Results based on Equation 4 led to the conclusion that there was a small significant moderating effect of MNCEQTY. Figure 1 shows that the TTDEG-CPERF relationship is stronger (i.e. steeper slope) for minor/majority ownership by MNCs as compared to 50/50 equal ownership between JV partners.

The coefficients table for HRPERF as shown in Table 4 depicts the results of the regressions equation for Model 1 and Model 2. Model 1 indicates that TTDEG was statistically significant $(p<0.001$; Beta value $=.746$ ); however MNCEQTY was not statistically significant $(p>0.05)$. Equation 5 below shows that for a 1-point increase in TTDEG, the HRPERF is predicted to have a difference by .425 , given that the MNCEQTY is held constant. The regression coefficient associated with MNCEQTY means that the difference in HRPERF between 50/50 equal ownership between MNCs and local JV partners and minor/majority ownership by MNCs is -.153, given that TTDEG is held constant.

$$
\text { Equation 5: }=3.836+.425 \mathrm{TTDEG}-.153 \mathrm{MNCEQTY}
$$

Model 2 shows the results after the product term (TTDEG*MNCEQTY) was included in the equation. As indicated in Table 2 the inclusion of product term resulted in an $R^{2}$ change of $.035,[F(1,124)=10.385, p<$ 0.01]. TTDEG, MNCEQTY and TTDEG*MNCEQTY were found highly significant $(p<0.001$, Beta value $=$ $1.286 ; p<0.05$, Beta value $=.883 ; p<0.05$, Beta value $=-1.206$, respectively). The results show the presence of 
a significant moderating effect. Table 4 also reveals information on the regression coefficients after the inclusion of product term in the equation. The equation for Model 2 is as follows:

$$
\text { Equation 6: } \quad \text { HRPERF }=-10.882+.733 \text { TTDEG }+3.651 \mathrm{MNCEQTY}-.078 \mathrm{TTDEG} * \mathrm{MNCEQTY}
$$

The result for Model 2 indicates that for a 1-point increase in the TTDEG, the HRPERF is predicted to have a difference by .733 , given that MNCEQTY is held constant. The interpretation of the regression coefficients for the product term in Equation 6 is that there was a -.078 difference between the slopes of HRPERF on TTDEG between 50/50 equal ownership between JV partners and minor/majority ownership by MNCs. The slope regressing HRPERF on TTDEG is steeper for minor/majority ownership by MNCs as compared to 50/50 equal ownership between JV partners. The TTDEG-HRPERF relationship for 50/50 equal ownership between JV partners and minor/majority ownership by MNC is also shown in Figure 1 below. The value of the mean score for TTDEG is 6.19 and for the standard deviation $(S D)$ is 1.30 . The value $1 S D$ above the mean is 7.49 , and the value $1 S D$ below the mean is 4.89 . Thus, using the value of $1 S D$ above and $1 S D$ below mean in Equation 6 yields the graph shown in Figure 1. Results based on Equation 6 led to the conclusion that there was a significant moderating effect of MNCEQTY. Figure 1 below indicates that the TTDEG-HRPERF relationship is stronger (i.e. steeper slope) for 50/50 equal ownership between JV partners as compared to minor/majority ownership by MNCs.

\section{Discussion and Conclusion}

Building on the underlying KBV and OL perspectives, this study has bridged the literature gaps by providing empirical evidence and new insights on the significant moderating effects of MNCs' equity ownership in the relationships between degree of inter-firm technology transfer and two dimensions of local firms' performance: corporate and human resource performances using the Malaysia sample. In comparison, the results suggest that the inclusion of MNCEQTY (50/50 equal ownership between MNCs and local JV partners vs. minor/majority ownership by MNCs) in TTDEG-LFP relationship has similar significant moderating effects in changing both local firms' corporate performance (CPERF) ( $p<0.10 ; R$ - squared change of 0.013$)$ and local firms' human resource performance (HRPERF) $(p<0.01 ; R$ - squared change of 0.035$)$. The moderating effect of MNCEQTY is shown to be capable of changing the nature of relationship and further explains under what conditions TTDEG causes CPERF and HRPERF. This means the presence of significant moderating effect of MNCEQTY (50/50 equal ownership between JV partners and minor/majority ownership by MNCs) exceeded the linear relationship between TTDEG and both CPERF and HRPERF. The results are consistent with literature which has strongly supported the significant role of MNCEQTY (Lyles and Salk, 1996; Harrigan, 1986; Salk, 1992).

The results also suggest that MNCEQTY; whether 50/50 equal ownership between MNCs and local JV partners or minor/majority ownership by MNCs, has been established to provide a significant moderating effect in 1) TTDEG-CPERF relationship; where the relationship was found stronger for minor/majority ownership by MNCs as compared to 50/50 equal ownership between JV partners, and 2) TTDEG-HRPERF relationship; where the relationship was found stronger for 50/50 equal ownership between JV partners. The results provide critical information in such that although a successful technology transfer in IJVs; which includes the transfer of substantial tacit and explicit knowledge could have significantly increased 1) the corporate performance in terms the local firms' business volume, market share, planned goals and profits, and 2) the human resource performance in terms of local firms' product/service quality, employees' productivity, managerial techniques/skills and operational efficiency, nevertheless, organizational learning and acquiring new technological knowledge in JVs with shared management is rather difficult when there is no clear dominant control by any partner in the decision making process especially on the day-to-day managerial affairs and management of assets and resources. The IJVs with shared management are more likely to encounter difficulties when cultural differences are present. The differences in culture, language, educational background and distance with cross national partners could act as barriers to inter-organizational learning thus impeding knowledge transfer in IJVs (Mowery et al. 1996). Due to these cultural distances, a shared management IJVs is more unlikely to transfer a higher degree or technology to local partners. As a result, this will indeed frustrate and dampen the recipient partners' organizational learning process; especially when conflicts; which are most likely to arise from cultural differences, inhibit the transfer process.

On the other hand, the MNCs with minor equity ownership in IJVs will normally become cautious and selective to transfer their strategic valuable resources, competencies and source of sustainable competitive advantage of the MNCs (Porter, 1985; Barney, 1991; Peteraf, 1993; Wernerfelt, 1984; Pralahad and Hamel, 1990); especially when they have less control/ability to influence the systems, methods and decisions; which is frequently associated with higher resources commitment and equity interests. In this circumstance, as technology flows are strictly restricted and controlled, therefore even if technologies are intentionally transferred their effects on local firms' corporate and human resource performances could be very minimal. In comparison, due to their 'technology superiority', the MNCs with majority equity ownership in IJVs have frequently perceived that their JVs as one-way learning processes thus having little to share with local partners (Liu and Vince, 1999; Danis and Parkhe, 2002). Since learning in IJVs is asymmetrical, the MNCs with majority equity ownership view organizational learning as solely the task of the knowledge-disadvantaged local partners (Lin, 2005). By limiting the flows of their valuable technologies, the local JV partners might not have much to learn thus resulting in no significant improvement on local firms' corporate and human resource performances. The results further extend the findings made by Lyles and Salk (1996) and Pak and Park (2004) by empirically establishing that 
MNCEQTY has significantly influenced the relationship between degree of inter-firm technology transfer and local firms' performance.

One of the major limitations encountered by this study was the resource constraints; where this study has mainly relied on responses obtained from the top management level of the IJVs. Thus, the scope of respondents could have been extended to include the response from middle and lower management levels in the JVs. Secondly, consistent with the literature, the subjectivity of nature of relationship is difficult to capture. Thus, the nature of relationship between IJV partners could have tremendously affected the results if the respondents perceived that the IJVs that they involved in were competitive in nature rather than collaborative. Thirdly, due to lack of awareness on academic research the response rate in terms of the number of usable questionnaires, though sufficient, was not encouraging. This has become a major challenge to many researchers who conduct organization studies in Malaysia. Finally, due to time constraints, the types of technology under investigation in this study were limited to tacit vs. explicit knowledge dimension.

This empirical study is a response to the need for statistical evidence that has typically been lacking in inter-firm TT literature. Since this study focuses on degree of inter-firm TT and local firms' performance, future studies could be conducted to further examine the moderating effects of MNCs' equity ownership in the relationships between degree of technology transfer and other critical dependent variable such as partners' conflict, learning outcomes, asymmetric bargaining power, stability of IJVs and equity ownership. Secondly, the above relationship could also be extended to cover other formal and externalized inter-firm TT agents such as direct exporting, FDIs and licensing. Thirdly, it is worthwhile to extend the degree of technology transfer's dimension (tacit vs. explicit dimension) to cover other dimensions of supply chain activities such as production, marketing, management, and distribution. Finally, future studies could further investigate the effects of few other established moderating variables such as organizational culture, collaborative know-how, prior JV experience, and learning capacity on the above relationships to provide new insights and information on the boundary conditions for degree of technology transfer-local firms' performance relationship.

\section{References}

Aguinis, H. (2004). Regression Analysis for Categorical Moderators. New York, The Gilford Press.

Aiken, L. S., \& West, S. G. (1991). Multiple Regression: Testing and Interpreting Interacting. Newbury Park, CA: Sage.

Allen, D. R., \& Rao, T. R. (2000). Analysis of Customer Satisfaction Data. United States of America: America Society for Quality.

Anderson, E \& Gatignon, H. (1986). Models of Foreign Entry: A Transaction Cost Analysis and Propositions. Journal of International Studies, 17 (3), p. 1-26.

Barney, J.B. (1991). Firm Resources and Sustained Competitive Advantage. Journal of Management, 17, p. 151-166. http://dx.doi.org/10.1177/014920639101700108

Blomstrom, M. (1990). Transnational Corporations and Manufacturing Exports from Developing Countries. New York, United Nations.

Bresman, H., Birkinshaw, J., \& Nobel, R. (1999). Knowledge Transfer in International Acquisitions. Journal of International Business Studies, 30(3), p. 439-62.

Caves, R.E. (1974). Multinational Firms, Competition and Productivity in Host-Country Markets. Economica, 41, p. 176-193. http://dx.doi.org/10.2307/2553765

Chen, E.K.Y. (1996). Transnational Corporations and Technology Transfer to Developing Countries in UNCTAD, Transnational Corporations and World Development, p. 181-214. London, UK: Thompson Business Press.

Chung, W. (2001). Identifying Technology Transfer in Foreign Direct Investment: Influence of Industry Conditions and Investing Firm Motives, Journal of International Business Studies, 32(2), p. 211-229. http://dx.doi.org/10.1057/palgrave.jibs.8490949

Cohen, J., \& Cohen, P. (1983). Applied Multiple Regression/Correlational Analysis for the Behavioral Sciences $\left(2^{\text {nd }}\right.$ ed.). Hillsdale, NJ: Erlbaum.

Cui, A.S, Griffith, D.A., Casvugil, S.T., \& Dabic, M. (2006). The Influence of Market and Cultural Environmental Factors on Technology Transfer between Foreign MNCs and Local Subsidiaries: A Croatian Illustration. Journal of World Business; 41; p. 100-111. http://dx.doi.org/10.1016/j.jwb.2006.01.011

Cumming, J.L., \& Teng, B.S. (2003). Transferring R\&D Knowledge: The Keys Factors Affecting Knowledge Transfer Success. Journal of Engineering and Technology Management, 20, p. 39-68. http://dx.doi.org/10.1016/S0923-4748(03)00004-3

Danis, W.M., \& Parkhe, A. (2002). Hungarian-Western Partnership: A Ground Theoretical Model of Integration Processes and Outcomes. Journal of Business Studies, 33(3), p. 423-455. http://dx.doi.org/10.1057/palgrave.jibs.8491025

Dess, G. G., \& Robinson, R. B. J. (1984). Measuring Organizational Performance in the Absence of Objective Measures: The Case of the Privately-Held Firm and Conglomerate Business Unit. Strategic Management Journal, 5 (3), p. 265-73. http://dx.doi.org/10.1002/smj.4250050306 
Dhanaraj, C., Lyles, M.A., Steensma, H.K., \& Tihanyi, L. (2004). Managing Tacit and Explicit Knowledge Transfer in IJVs: the Role of Relational Embeddedness and the Impact on Performance. Journal of International Business Studies, 35(5), p. 428-42. http://dx.doi.org/10.1057/palgrave.jibs.8400098

Geppert, M., \& Clark, E. (2003). Knowledge and Learning in Transnational Ventures: An Actor-Centred Approach. Management Decision, 41(5), pp.433-442. http://dx.doi.org/10.1108/00251740310479287

Geringer, J. M., \& Hebert, L. (1991). Measuring Performance of International Joint Ventures, Journal of International Business Studies, 22(2), p. 249 - 63. http://dx.doi.org/10.1057/palgrave.jibs.8490302

Grosse, R. (1996). International Technology Transfer in Services. Journal of International Business Studies, 27(4), p. 781-800. http://dx.doi.org/10.1057/palgrave.jibs.8490153

Guan, J. C., Mok, C. K., Yam, C.M. \& Pun, K. F. (2006). Technology Transfer and Innovation Performance: Evidence from Chinese Firms. Technological Forecasting and Social Change, 73, p.666-678. http://dx.doi.org/10.1016/j.techfore.2005.05.009

Gupta, A. K., \& Govindarajan, V. (2000). Knowledge Flows within Multinational Corporations. Strategic Management Journal, $\quad 21(4), \quad$ p. $\quad 473-96$. http://dx.doi.org/10.1002/(SICI)1097-0266(200004)21:4<473::AID-SMJ84>3.0.CO;2-I

Harrigan, K.R. (1984). Joint Ventures and Global Strategies. Columbia Journal of World Business, 19(2), p. 7-16.

Harrigan, K.R. (1984). Managing for Joint Venture Success. Lexington, Mass: Lexington Books.

Hau, L. N. \& Evangelista, F. (2007). Acquiring Tacit and Explicit Markrting Knowledge from Foreign Partners in IJVs. Journal of Business Research, 60, pp. 1152-1165. http://dx.doi.org/10.1016/j.jbusres.2007.04.006

Inkpen, A. C. (1998a). Learning and Knowledge Acquisition through International Strategic Alliances. The Academy of Management Executive, 12(4), p. 69-80.

Inkpen, A.C \& Dinur, A. (1998). Knowledge Management Processes and International Joint Ventures. Organization Science, 9(4), p. 454-468. http://dx.doi.org/10.5465/AME.1998.1333953

Inkpen, A.C. (2000). Learning through Joint Ventures: A Framework of Knowledge Acquisition. Journal of Management Studies, 37(7), p. 1019-1043. http://dx.doi.org/10.1287/orsc.9.4.454

Inkpen, A.C., \& Beamish, P.W. (1997). Knowledge Bargaining Power and the Instability of International Joint Ventures. Academy of Management Review, 22(1), p. 177-199. http://dx.doi.org/10.1111/1467-6486.00215

Jaccard, J. J., Turrisi, R., \& Wan, C. K. (1990). Interaction Effects in Multiple Regression. Newbury Park, CA: Sage.

Killing, J. P. (1983). Strategies for Joint Venture Success. New York: Praeger.

Kogut, B. (1988). Joint Ventures: Theoretical and Empirical Perspectives. Strategic Management Journal, 9(4), p. 319-32. http://dx.doi.org/10.1002/smj.4250090403

Kogut, B., \& Zander, U. (1993). Knowledge of the Firm and the Evolutionary Theory of the Multinational Corporation. Journal of International Business Studies, 24(4), p. $625-646$. http://dx.doi.org/10.1057/palgrave.jibs.8490248

Kotabe, M., Dunlap-Hinkler, D., Parente, R., \& Mishra, H. (2007). Determinants of Cross-National Knowledge Transfer and Its Effect on Firm Innovation. Journal of International Business Studies, 38, p. $259-282$.

http://dx.doi.org/10.1057/palgrave.jibs.8400261

Kumar, V., Kumar, U., \& Persaud, A. (1999). Building Technological Capability through Importing Technology: The Case of Indonesian Manufacturing Industry. Journal of Technology Transfer, 24, p. 81-96. http://dx.doi.org/10.1023/A:1007728921126

Lai, Y.W., \& Narayanan, S. (1997). The Quest for Technological Competence via MNCs: A Malaysian Case Study. Asian Economic Journal, 11(4), p. 407-422. http://dx.doi.org/10.1111/1467-8381.00045

Lam, A. (1997). Embedded Firms, Embedded Knowledge: Problems of Collaboration and Knowledge Transfer In Global Cooperative Venture. Organization Studies, $18(6), \quad$ pp.973-996. http://dx.doi.org/10.1177/017084069701800604

Lane, P. J., Salk, J.E., \& Lyles, M.A. (2001). Absorptive Capacity, Learning, and Performance in International Joint Ventures. Strategic Management Journal, 22(12), p. 1139-61. http://dx.doi.org/10.1002/smj.206

Liao, S.H., \& Hu, T.C. (2007). Knowledge Transfer and Competitive Advantage on Environmental Uncertainty: An Empirical Study of the Taiwan's industry. Technovation, 27, p. $402-411$. http://dx.doi.org/10.1016/j.technovation.2007.02.005

Lin, W.B. (2007). Factors Affecting the Correlation between Interactive Mechanisms of Strategic Alliance and Technological Knowledge Transfer Performance. The Journal of High Technology Management Research, 17, p. 139-155. http://dx.doi.org/10.1016/j.hitech.2006.11.003

Lin, X. (2005). Local Partner Acquisition of Managerial Knowledge in International Joint Ventures: Focusing on Foreign Management Control. Management International Review, 45(2), p. 219-237.

Liu, S., \& Vince, R. (1999). The Cultural Context of Learning in International Joint Ventures. Journal of 
Management Development, 18 (8), p. 666-675. http://dx.doi.org/10.1108/02621719910293765

Liu, X., \& Wang, C. (2003). Does Foreihn Direct Investment Facilitate Technological Progress? Evidence from Chinese Industries. Research Policy, 32, p. 954-953. http://dx.doi.org/10.1016/S0048-7333(02)00094-X

Luo, Y., \& Peng, M.W. (1999). Learning in a Transition Economy: Experience, Environment, and Performance. Journal of International Business Studies, 30(2), pp. 269-296. http://dx.doi.org/10.1057/palgrave.jibs.8490070

Lyles, M. A., \& Barden, J. Q. (2000). Trust, Controls, Knowledge Acquisition from the Foreign Parents and Performance in Vietnamese IJVs. Submission to the International Management Division of the AOM meeting.

Lyles, M. A., \& Salk, J.E. (1996). Knowledge Acquisition from Foreign Parents in International Joint Ventures: An Empirical Examination in the Hungarian. Journal of International Business Studies, 29(2), p. 154-74.

Madanmohan, T.R., Kumar, U., \& Kumar, V. (2004). Import-led Technological Capability: A Comparative Analysis of Indian and Indonesian Manufacturing Firms. Technovation, p. 979-993. http://dx.doi.org/10.1016/S0166-4972(03)00030-0

Makhija, M.V., \& Ganesh, U. (1997). The Relationship between Control and Partner Learning-Related Joint Ventures. Organization Science, 8(5), p. 508-527. http://dx.doi.org/10.1287/orsc.8.5.508

Markusen, J.R., \& Venables, A.J. (1999). Foreign Direct Investment as a Catalyst for Industrial Development. European Economic Review, 43, p.335-356. http://dx.doi.org/10.1016/S0014-2921(98)00048-8

Marquardt, M., \& Reynolds, A. (1994). Global Learning Organizations. New York: Irwin

Minbaeva, D. (2007). Knowledge Transfer in Multinationals. Management International Review, 47(4), p. 567-593. http://dx.doi.org/10.1007/s11575-007-0030-4

Mohamed, M.Z. (1998). Assessing the Competitiveness of the Malaysian Electronic and Electrical Industry: Part 1-Technology Adoption. Malaysian Management Review, 33(10), p. 19-20.

Mowery, D.C., Oxley J.E., \& Silverman B.S. (1996). Strategic Alliances and Interfirm Knowledge Transfer. Strategic Management Journal, 17, p. 77-91.

Narayanan, S., \& Lai, Y. W. (2000). Technological Maturity and Development without Research: The Challenge for Malaysian Manufacturing. Development and Change, 31, p. 435-457. http://dx.doi.org/10.1111/1467-7660.00161

Pak, Y., \& Park, Y. (2004). A Framework of Knowledge Transfer in Cross-Border Joint Ventures: An Empirical Test of the Korean Context. Management International Review, 44(4), p. 435-455.

Petaraf, M.A. (1993). The Cornerstone of Competitive Advantage: A Resourced-Based View. Strategic Management Journal, 14(3), p. 179-192. http://dx.doi.org/10.1002/smj.4250140303

Porter, M.E. (1985). Competitive Advantage: Creating and Sustaining Superior Performance. Free Press: New York.

Pralahad, C.K., \& Hamel, G. (1990). The Core Competence of the Corporation. Harvard Business Review, 68, p. 77-91.

Rodriguez, J.L., \& Rodriguez, R.M.G. (2005). Technology and Export Behaviour: A Resource-Based View Approach. International Business Review, 14, p. 539-557. http://dx.doi.org/10.1016/j.ibusrev.2005.07.002

Salk, J. E. (1992). Shared Management Joint Venture: Their Developmental Patterns, Challenges, and Possibilities. Unpublished Ph.D Dissertation, Sloan School of Management, Massachusetts Institute of Technology, Cambridge, Massachusetts.

Sekaran, U. (2003). Research Methods for Business, Fourth Edition. John Wiley \& Sons, Inc.

Si, S. X., \& Bruton, G. D. (1999). Knowledge Transfer in International Joint Ventures in Transitional Economy: The China Experience. The Academy of Management Executive, 13(1), p. 83-90. http://dx.doi.org/10.5465/AME.1999.1567354

Simonin, B. L. (1999a). Ambiguity and the Process of Knowledge Transfer in Strategic Alliances. Strategic

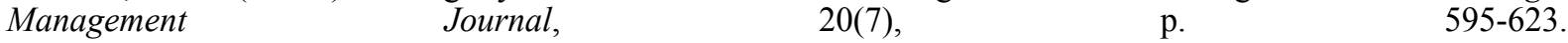
http://dx.doi.org/10.1002/(SICI)1097-0266(199907)20:7<595::AID-SMJ47>3.0.CO;2-5

Simonin, B. L. (2004). An Empirical Investigation of the Process of Knowledge Transfer in International Strategic Alliances, Journal of International Business Studies, 35(5), 407-27. http://dx.doi.org/10.1057/palgrave.jibs.8400091

Simonin, B.L. (1999b). Transfer of Marketing Know-how in International Strategic Alliances: An Empirical Investigation of the Role and Antecedents of Knowledge Ambiguity. Journal of International Business Studies, 30(3) p. 463-90 [Third Quarter]. http://dx.doi.org/10.1057/palgrave.jibs.8490079

Steensma, H. K., \& Lyles, M.A. (2000). Explaining IJV Survival in a Transitional Economy through Social Exchange and Knowledge-based perspectives, Strategic Management Journal, 21(8), p. 831-51. http://dx.doi.org/10.1002/1097-0266(200008)21:8<831::AID-SMJ123>3.0.CO;2-H

Subramaniam, M., \& Venkatraman, N. (2001). Determinants of Transnational New Product Development Capability: Testing the Influence of Transferring and Deploying Tacit Overseas Knowledge. Strategic Management Journal, 22(4): 359-378. http://dx.doi.org/10.1002/smj.163 
Tsang E.W.K., Tri D.N., \& Erramilli M.K. (2004). Knowledge Acquisition and Performance of International Joint Ventures in the Transition Economy of Vietnam. Journal of International Marketing, 12(2), p. 82-103. http://dx.doi.org/10.1509/jimk.12.2.82.32901

Tsang, E.W.K. (2001). Managerial Learning in Foreign-Invested Enterprises of China. Management International Review, 41 (1), 29-51.

Wernerfelt, B. (1984). A Resource-Based View of the Firm. Strategic Management Journal, 5(2), p. 171- 80. http://dx.doi.org/10.1002/smj.4250050207

Wong, Y. Y., Maher, T. E., \& Luk, T. K. (2002). The Hesitant Transfer of Strategic Managerial Knowlegde to International Joint Ventures in China: Greater Willingness Seems Likely in the Future. Management Review News, 25(1), pp. 1-16. http://dx.doi.org/10.1108/01409170210782981

Yin, E., \& Bao, Y. (2006). The Acquisition of Tacit Knowledge in China: An Empirical Analysis of the 'Supplier-side Individual Level' and 'Recipient-side' Factors. Management International Review, 46(3), p. 327-348. http://dx.doi.org/10.1007/s11575-006-0050-5

Table 1. Model Summary - Corporate Performance

Model Summaryc

\begin{tabular}{|c|c|c|c|c|c|c|c|c|c|}
\hline \multirow[b]{2}{*}{ Model } & \multirow[b]{2}{*}{$\mathrm{R}$} & \multirow[b]{2}{*}{ R Square } & \multirow[b]{2}{*}{$\begin{array}{l}\text { Adjusted } \\
\text { R Square }\end{array}$} & \multirow[b]{2}{*}{$\begin{array}{l}\text { Std. Error of } \\
\text { the Estimate }\end{array}$} & \multicolumn{5}{|c|}{ Change Statistics } \\
\hline & & & & & $\begin{array}{c}\text { R Square } \\
\text { Change }\end{array}$ & F Change & df1 & $\mathrm{df} 2$ & Sig. F Change \\
\hline 1 & $.674^{\mathrm{a}}$ & .455 & .446 & 5.207 & .455 & 52.137 & 2 & 125 & .000 \\
\hline 2 & $.684^{\mathrm{b}}$ & .468 & .455 & 5.165 & .013 & 3.072 & 1 & 124 & .082 \\
\hline
\end{tabular}

a. Predictors: (Constant), MNCEQTY, TTDEG

b. Predictors: (Constant), MNCEQTY, TTDEG, TTDEG*MNCEQTY

c. Dependent Variable: CPERF

Table 2. Model Summary - Human Resource Performance

Model Summary

\begin{tabular}{|c|c|c|c|c|c|c|c|c|c|}
\hline \multirow[b]{2}{*}{ Model } & \multirow[b]{2}{*}{$\mathrm{R}$} & \multirow[b]{2}{*}{ R Square } & \multirow[b]{2}{*}{$\begin{array}{l}\text { Adjusted } \\
\text { R Square }\end{array}$} & \multirow[b]{2}{*}{$\begin{array}{l}\text { Std. Error of } \\
\text { the Estimate }\end{array}$} & \multicolumn{5}{|c|}{ Change Statistics } \\
\hline & & & & & $\begin{array}{l}\text { R Square } \\
\text { Change }\end{array}$ & F Change & df1 & df2 & Sig. F Change \\
\hline 1 & $.736^{\mathrm{a}}$ & .542 & .535 & 4.062 & .542 & 73.995 & 2 & 125 & .000 \\
\hline 2 & $.760^{\mathrm{b}}$ & .577 & .567 & 3.918 & .035 & 10.385 & 1 & 124 & .002 \\
\hline
\end{tabular}

a. Predictors: (Constant), MNCEQTY, TTDEG

b. Predictors: (Constant), MNCEQTY, TTDEG, TTDEG*MNCEQTY

c. Dependent Variable: HRPERF

Table 3. Coefficients ${ }^{\mathrm{a}}$ - Corporate Performance

Coefficients $^{\mathrm{a}}$

\begin{tabular}{|c|c|c|c|c|c|c|c|c|}
\hline & & \multicolumn{2}{|c|}{$\begin{array}{c}\text { Unstandardized } \\
\text { Coefficients }\end{array}$} & $\begin{array}{c}\text { Standardized } \\
\text { Coefficients }\end{array}$ & \multirow[b]{2}{*}{$\mathrm{t}$} & \multirow[b]{2}{*}{ Sig. } & \multicolumn{2}{|c|}{$95 \%$ Confidence Interval for B } \\
\hline \multicolumn{2}{|c|}{ Model } & B & Std. Error & Beta & & & Lower Bound & Upper Bound \\
\hline \multirow[t]{3}{*}{1} & (Constant) & .509 & 2.304 & & .221 & .825 & -4.050 & 5.069 \\
\hline & TTDEG & .445 & .046 & .665 & 9.662 & .000 & .354 & .537 \\
\hline & MNCEQTY & .145 & .334 & .030 & .435 & .664 & -.517 & .807 \\
\hline \multirow[t]{4}{*}{2} & (Constant) & -10.042 & 6.439 & & -1.560 & .121 & -22.788 & 2.703 \\
\hline & TTDEG & .666 & .134 & .995 & 4.972 & .000 & .401 & .931 \\
\hline & MNCEQTY & 2.873 & 1.591 & .591 & 1.806 & .073 & -.276 & 6.022 \\
\hline & TTDEG*MNCEQTY & -.056 & .032 & -.736 & -1.753 & .082 & -.119 & .007 \\
\hline
\end{tabular}

a. Dependent Variable: CPERF 
Table 4. Coefficients ${ }^{\mathrm{a}}$ - Human Resource Performance

Coefficients $^{\mathrm{a}}$

\begin{tabular}{|c|c|c|c|c|c|c|c|c|}
\hline \multirow{2}{*}{\multicolumn{2}{|c|}{ Model }} & \multicolumn{2}{|c|}{$\begin{array}{c}\text { Unstandardized } \\
\text { Coefficients }\end{array}$} & \multirow{2}{*}{$\begin{array}{c}\begin{array}{c}\text { Standardized } \\
\text { Coefficients }\end{array} \\
\text { Beta }\end{array}$} & \multirow[b]{2}{*}{$\mathrm{t}$} & \multirow[b]{2}{*}{ Sig. } & \multicolumn{2}{|c|}{$95 \%$ Confidence Interval for B } \\
\hline & & B & Std. Error & & & & Lower Bound & Upper Bound \\
\hline & (Constant) & 3.836 & 1.797 & & 2.134 & .035 & .279 & 7.393 \\
\hline & TTDEG & .425 & .036 & .746 & 11.820 & .000 & .354 & .496 \\
\hline & MNCEQTY & -.153 & .261 & -.037 & -.585 & .559 & -669 & .364 \\
\hline \multirow[t]{4}{*}{2} & (Constant) & -10.882 & 4.885 & & -2.228 & .028 & -20.551 & -1.213 \\
\hline & TTDEG & .733 & 102 & 1.286 & 7.212 & .000 & .532 & .934 \\
\hline & MNCEQTY & 3.651 & 1.207 & .883 & 3.025 & .003 & 1.262 & 6.040 \\
\hline & TTDEG*MNCEQTY & -.078 & .024 & -1.206 & -3.223 & .002 & -.126 & -.030 \\
\hline
\end{tabular}

a. Dependent Variable: HRPERF

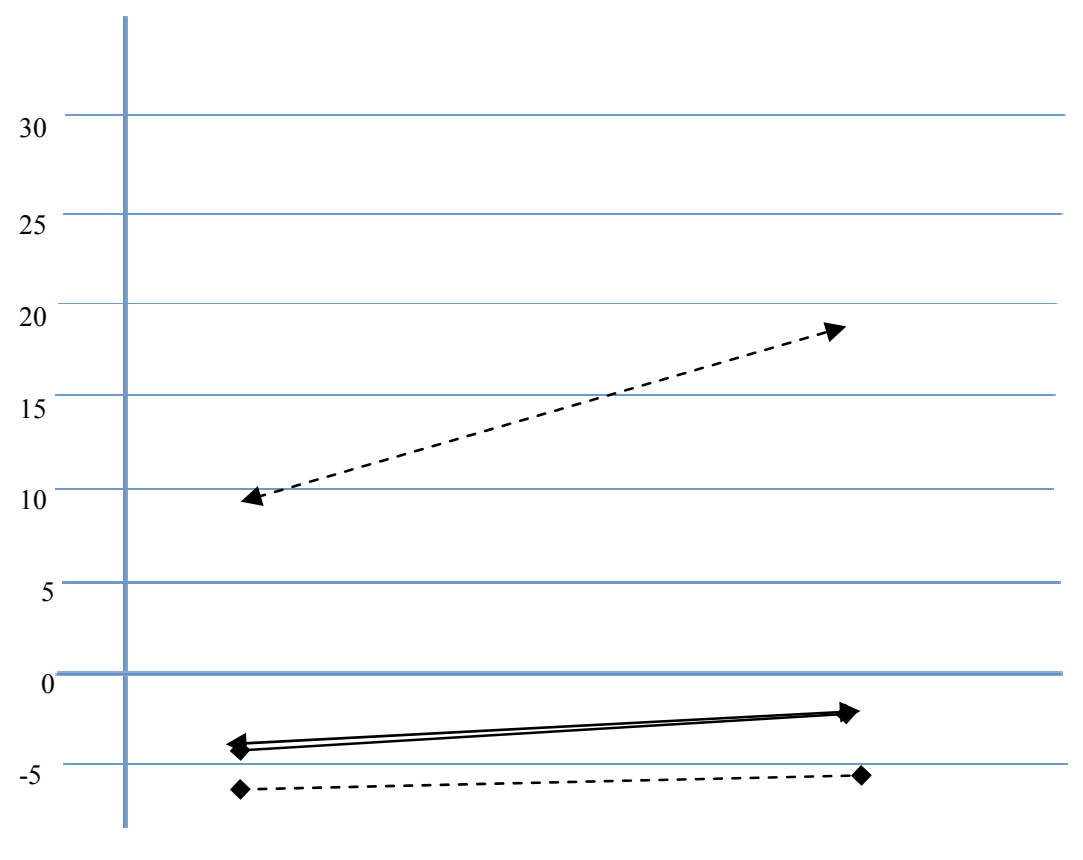

$-10$

Low CPERF / HRPERF (1 SD below mean)

High CPERF / HRPERF (1 $S D$ above mean)

$\prec$ Minor/Majority ownership by MNCs (CPERF)

$\bullet--\downarrow 50 / 50$ ownership by JV partners (CPERF)

Minor/Majority ownership by MNCs (HRPERF)

50/50 ownership by JV partners (HRPERF)

Figure 1. Slopes for Both CPERF and HRPERF on TTDEG for MNCEQTY

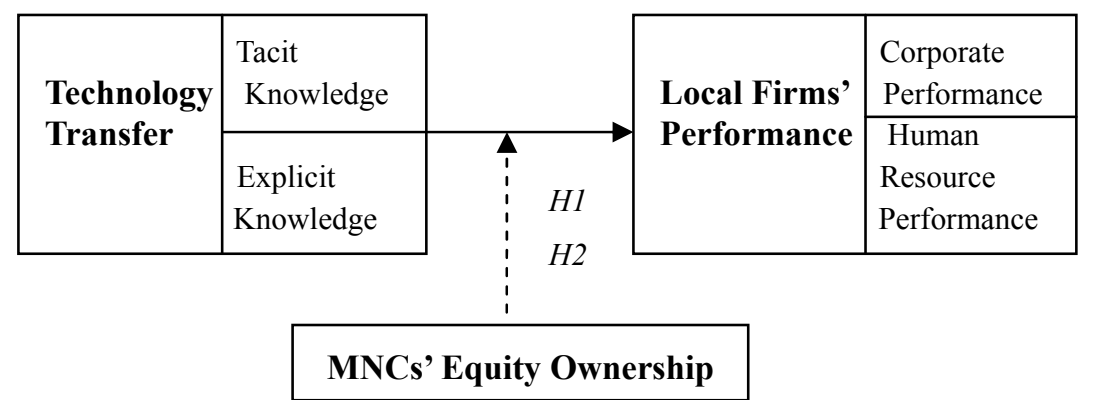

Figure 2. The Theoretical Model 